\title{
European Stroke Organisation (ESO)
}

\section{EUROPEAN STROKE ORGANISATION}

The European Stroke Organisation (ESO) is a Pan-European society of stroke researchers, national and regional stroke societies and lay people organisations that was founded in December 2007.

Official journal:

\section{Cerebrovascular Diseases}

\section{President:}

Michael Brainin, Austria

\section{President elect:}

Kennedy Lees, United Kingdom

\section{Past President:}

Didier Leys, France

Vice Presidents:

Angel Chamorro, Spain

Heinrich Mattle, Switzerland

\section{Secretary General:}

Patrik Michel, Switzerland

\section{Treasurer:}

Turgut Tatlisumak, Finland

\section{Members at Large:}

Natan Bornstein, Israel

Valeria Caso, Italy

Chair of Public Relations Committee:

Geert Vanhooren, Belgium

\section{More information at:} www.eso-stroke.org

\section{Why become a member of the ESO?}

The European Stroke Organisation (ESO) is a European society of stroke researchers, national, regional and non-professional stroke societies that was founded in December 2007. Key objectives of the ESO include the development of public policies to reduce the number of stroke-associated deaths and the reduction of the global burden caused by stroke throughout Europe. Its membership consists of stroke researchers, national and regional stroke societies, and others with an interest in stroke.

In addition to raising awareness of stroke on a Pan-European scale, one of the most important tasks of the ESO is to produce European guidelines for the management of stroke. ESO guidelines have been translated into more than ten languages. The latest update of the ischaemic stroke recommendations were implemented by the ESO in January 2009.

In May 2012 at the European Stroke Conference (ESC) in Lisbon, the new Executive Committee of the ESO was elected during the general assembly in order to decide upon the future of the organisation. All ESO members in good standing will be asked to vote or to run for one of the Executive Committee positions.

Become an ESO member and make an investment in your professional future.

Fees:

Junior member* free

${ }^{*}<35$ years; participation in the last ESC is required

$\begin{array}{ll}\text { Regular membership } & 100 € \\ \text { ESO fellow } & 200 € \\ \text { Organisation membership } & 500 €\end{array}$

Memberships begin on 1 January and end on 31 December.

\section{Membership Benefits:}

ESO members can choose between the following 2 benefits:

- Free access to Cerebrovascular Diseases online

- A discount of $€ 40$ on the following year's ESC registration fee

For members residing in a country designated by the World Bank rating as a low- or lowermiddle-income country, the dues for membership will be reduced to $€ 25$ per year for regular membership and $€ 50$ per year for fellow membership.

For members of a stroke society which is an organisational ESO member, the annual ESO membership fee is reduced by $€ 50$.

Members of the ESO can apply for a joint membership with the World Stroke Organisation for only an additional $€ 35$.

\section{If you have any questions, please contact the ESO Head Office:}

European Stroke Organisation (ESO)

Peter Merian-Strasse $\mathbf{8 0}$

4002 Basel / Switzerland

Phone +41 616867776

Fax +41616867788

Email esoinfo@congrex.com

Link to the ESO membership website:

www.eso-stroke.org/eso_membership.php?cid=21\&sid=1 